\title{
Oxygen Saturation in Childhood at High Altitude: A Systematic Review
}

Santiago Ucrós ${ }^{1}$, Claudia M. Granados ${ }^{2}$, Jose A. Castro ${ }^{3}$, Catherine M. Hill. ${ }^{4}$

${ }^{1}$ Department of Pediatrics. Fundación Santa Fe de Bogotá, Colombia. ${ }^{2}$ Departments of Pediatrics and Clinical Epidemiology and Biostatistics. Pontificia Universidad Javeriana, Bogotá, Colombia. ${ }^{3}$ Pulmonology Unit, Departments of Pediatrics, School of Medicine, Pontificia Universidad Católica de Chile, Santiago, Chile. ${ }^{4}$ School of Clinical \& Experimental Sciences. Faculty of Medicine, University of Southampton, UK. Southampton Children's Hospital, Southampton, UK.

\section{ABSTRACT}

Background: It is well known that oxygen saturation $\left(\mathrm{SpO}_{2}\right)$, measured by pulse oximetry, decreases as altitude increases. However, how $\mathrm{SpO}_{2}$ changes across childhood, and more specifically during sleep/wake states, at different high altitudes are less well understood. We aimed to perform a systematic review of all studies with direct $\mathrm{SpO}_{2}$ measurement in healthy children living at high altitude ( $>2500$ meters above sea level [masl]) to address these questions.

Methods: MEDLINE, EMBASE, and SciELO databases were searched up to December 2018. Two independent reviewers screened the literature and extracted relevant data.

Results: Of 194 references, 20 studies met the eligibility criteria. Meta-analysis was not possible due to the use of different oximeters and/or protocols for data acquisition and reporting of different $\mathrm{SpO}_{2}$ central tendency and dispersion measures. The most relevant findings from the data were: 1$) \mathrm{SpO}_{2}$ is lower as altitude increases; 2) at high altitude, $\mathrm{SpO}_{2}$ improves with age through childhood; 3) $\mathrm{SpO}_{2}$ is lower during 
sleep and feeding in comparison to when awake, this $\mathrm{SpO}_{2}$ gap between wake and sleep states is more evident in the first months of life and narrows later in life; 4) $\mathrm{SpO}_{2}$ dispersion (inter-individual variation) is higher at younger ages, and more so during sleep; 6) In 6/20 studies the $\mathrm{SpO}_{2}$ values were non-normally distributed with a consistent left skew.

Conclusions: At high altitude mean/median $\mathrm{SpO}_{2}$ increases in children with aging; a significant gap between wake and sleep states is seen in the first months of life, which narrows, as the infant gets older; $\mathrm{SpO}_{2}$ dispersion at high altitude is wider at younger ages; at high altitude $\mathrm{SpO}_{2}$ shows a non-normal distribution skewed to the left, this bias becomes more evident as altitude increases, at younger ages and during sleep.

\section{Introduction}

Since its description in 1975 , oxygen saturation $\left(\mathrm{SpO}_{2}\right)$ measured by pulse oximetry (Severinghaus, 2007) has become a routine tool in clinical practice, to the point that it has been proposed as a new vital sign (Mower et al., 1997). $\mathrm{SpO}_{2}$ is a cheap, accessible, and portable tool used extensively in acute care, being especially important for acute respiratory infection categorization in infants and children (Lazzerini et al., 2015).

Around 140 million people worldwide live permanently at high altitude (Moore, 2001), where settlements are characterized by hypobaric hypoxia. No prior systematic review has considered normal reference data for resting daytime $\mathrm{SpO}_{2}$ levels across childhood at different high-altitude locations, nor considered the impact of sleep and 
infant feeding on $\mathrm{SpO}_{2}$. Only through understanding normal variation can treatment thresholds be determined for acute infections such as pneumonia and bronchiolitis and chronic illness such as bronchopulmonary dysplasia, cystic fibrosis and post infectious bronchiolitis obliterans. Expected $\mathrm{SpO}_{2}$ characteristics during sleep at high altitude are also important to interpret polysomnographic findings (Hill et al., 2016). ${ }^{\text {a }}$

In the decade since Subhi (Subhi et al., 2009), published a systematic review of normal $\mathrm{SpO}_{2}$ values in high altitude resident healthy infants and children up to 12 years of age, oximeter technology has progressed. We aimed to extend and update this review to include pulse oximetry studies at high altitude across childhood, including teenagers, and taking in account the differences in wake, sleep and feeding states, especially in infants.

\section{METHODS}

We identified published studies in MEDLINE, EMBASE, and SCielo (up to December 2018) databases, using the search terms: "(oxygen saturation) AND (high altitude)" restricted to child (birth to 19 years old) without language restriction; high altitude was defined as altitude $>2500$ meters above sea level (masl) (Moore 2001). Studies published solely in abstract form were excluded because the methods and results could not be fully analyzed. In addition, we searched other non-bibliographic data sources such as web searching. Only studies of healthy individuals habitually living at high altitude were included. Exclusion criteria included: 1) studies limited to $\mathrm{SpO}_{2}$ measurement uniquely during the first 24 hours of life as $\mathrm{SpO}_{2}$ has important changes during this period (González et al.,2005); 2) data collected across a range of altitudes greater than $\pm 50 \mathrm{~m}$ (for example between 3800 to 4200 masl), where it 
was not possible to identify the number of individuals located at a specific altitude and, 3) studies that included children with acute or chronic cardiorespiratory disorders, chronic ill health or history of prematurity.

Data extraction and assessment of risk of bias: titles, abstracts, and citations were independently reviewed by two authors (S.U. and C.G.). Based on the full text versions, all the studies were evaluated and after obtaining full reports, eligibility was assessed. Disagreements were discussed and resolved by consensus, and, when necessary, advice was sought from the third review author (J.C-R.). The risk of bias was evaluated according to the Newcastle-Ottawa Scale (Wells GA, et al., 2011). For methodological and reporting quality a pre-specified data analysis included year, country, altitude, type of study, number of participants, age range, $\mathrm{SpO}_{2}$ median/mean and $\mathrm{SpO}_{2}$ dispersion measurements. The pulse oximetry device used and the duration of $\mathrm{SpO}_{2}$ recording were also searched. We also looked at whether hemoglobin $(\mathrm{Hb})$ concentration measurements were reported.

Meta-analysis was not performed due to the variation between studies in oximeter devices, protocols and the central tendency (e.g. mean/median) and dispersion measures (e.g. standard deviation, interquartile range, $5^{\text {th }} / 95^{\text {th }}$ percentile) to report $\mathrm{SpO}_{2}$ values.

Using original source data from the Rojas-Camayo study (Rojas-Camayo et al., 2018) the $\mathrm{SpO}_{2}$ values from the first quartile were compared with those from the second to fourth quartiles grouped using RV 3.6.1 (July 2019 version) software. The comparison was made for three altitude levels (2,500, 3,600 and 5,100 masl) and for two age groups (1-5 and 6-17 years old). Statistical differences were determined 
using the $T$ test when the Shapiro-Wilk test showed a $p$-value $<0.05$, otherwise the Mann Whitney test was used.

\section{RESULTS}

One hundred and ninety-four studies were retrieved from the databases, of which 20 were eligible for inclusion (Figure 1). Most of the studies $(n=14)$ came from the South America Andean region (Peru=4, Bolivia=4, Colombia=3, Ecuador=2, Argentina=1); three studies were from China, two from the USA, and one from Nepal. Seventeen studies reported $\mathrm{SpO}_{2}$ data during wakefulness, (Alduncín et al., 2005; Beall 2000; Duenas-Meza et al., 2015; Gamponia et al.,1998; Hill et al., 2016; Huicho et al., 2001; Lozano et al.,1992; Mattos et al., 2005; Nicholas et al., 1993; Niermeyer et al.,1993; Niermeyer et al., 1995; Ramírez-Cardich et al., 2004; Rojas-Camayo et al., 2018; Torres et al.,1999; Schult et al., 2011; Shrestha et al., 2012 and Weitz et al., 2007). Nine studies reported $\mathrm{SpO}_{2}$ data during sleep (Hill et al., 2016; DueñasMeza et al., 2015; Gamponia et al.,1998; Niermeyer et al.,1993; Niermeyer et al., 1995; Ramírez-Cardich et al., 2004; Torres et al.,1999; Ucrós et al., 2015 and Ucrós et al., 2017); four studies reported data in infants during feeding (Gamponia et al., 1998 Niermeyer et al., 1995; Ramírez-Cardich et al., 2004 and Torres et al., 1999;) and one study when infants were crying (Gamponia et al., 1998). One study was published in a Colombian journal not identified by the search but was known by the authors (Torres et al., 1999). All studies were cross-sectional, except one, which had a longitudinal component (Duenas-Meza et al., 2015). The total number of $\mathrm{SpO}_{2}$ records sampled in these 20 studies were 6877 during wakefulness, 923 during 
sleep, and 528 in infants during feeding. The pulse oximetry device used and the sampling protocols were diverse (Table 1). The quality assessment of most studies was high with a low risk of bias.

\section{Studies in the wake and sleep states}

The results of studies for $\mathrm{SpO}_{2}$ during the wake state are shown in Tables 2, 3 and 4 across three different geographic regions. Sleep data are shown in Table 5. The most relevant findings are as follows: diurnal awake $\mathrm{SpO}_{2}$ is lower as altitude increases (for illustrative data see Figure 2) and is lower at the same altitude during sleep and infant feeding in comparison to the wake state; in younger children the range of normal diurnal $\mathrm{SpO}_{2}$ increases with increasing altitude, so for example, varying by $5 \%$ in children aged 1 to 5 years at 2500 masl, in comparison with $12 \%$ in the same age group at 5100 masl, with this phenomenon being more marked during sleep. At high altitude $\mathrm{SpO}_{2}$ increases with age and a significant gap between wake and sleep states occurs in the first months of life and narrows as the age increases, for example, Hill et al report that at 3700 masl, the median difference in infants 6 to 10 months old between the wake vs. sleep stage is $6 \%$, compared to $3 \%$

between the ages of 13 to 17 years (Hill CM., ${ }^{\text {b }}$ et al. 2016) (Figure 3). $\mathrm{SpO}_{2}$ dispersion at high altitude is wider at younger ages (for illustrative data see Figure 4), and $\mathrm{SpO}_{2}$ peak values are attained at older ages as altitude increases.

\section{Studies during infant feeding and crying}


Five studies analyzed $\mathrm{SpO}_{2}$ during feeding in infants up to five months of age at high altitude (Table 6). The data show a $\mathrm{SpO}_{2}$ decrease between $0.2 \%$ to $6 \%$ when wake and feeding states are compared, with a mean decrease of $-2.2 \%$. Only one study reported $\mathrm{SpO}_{2}$ differences in infants when crying compared to quiet wakefulness (Gamponia et al., 1998); this study included 19 infants 0 to 5 months of age at 4018 masl, and noted a $0.8 \%$ decrease in median $\mathrm{SpO}_{2}$ in crying infants.

\section{Studies reporting ethnicity and gender influences}

Three studies reported the influence of ethnicity and sex on waking $\mathrm{SpO}_{2}$ variables. One study in Tibet at 3200 masl (Weitz et al., 2007) reported a significant sex byethnicity interaction in 15-19 yr-olds, such that Tibetan females had higher $\mathrm{SpO}_{2}$ values than Tibetan males, but among Chinese Han born at this high altitude, males had higher $\mathrm{SpO}_{2}$ values than females (the Han population originate from lowland plains in Eastern China). A study from Peru at 4100 masl found no differences in $\mathrm{SpO}_{2}$ values between males and females, but children from the Nuñoa ethnicity had higher $\mathrm{SpO}_{2}$ levels in comparison with children from Tintayá and Marquirí ethnicities (Huicho et al., 2001), all ethnicities being highlanders. Finally, a study at 3800 masl

reported that Tibetan 5-9-yr-olds had significantly higher $\mathrm{SpO}_{2}$ values than Han children did at the same age (Niermeyer et al., 1995).

\section{Statistical distribution}

In 12/20 studies a normal distribution was assumed by the authors who reported mean values, but without specification of the statistical test used to reach this conclusion. In 2/20 a non-normal distribution can be deducted from the data, but the 
statistical bias is not known; in 6/20 studies a left skewed non-normal distribution was found (Hill et al., 2016a; Hill et al., 2016 ${ }^{\text {b; }}$ Rojas-Camayo et al., 2018;Torres et al., 1999; Ucrós et al., 2015, Ucrós et al., 2017). A review of the source data from studies by Hill and Rojas-Camayo confirmed that the data distribution has a negative bias. In Figure 5, the $\mathrm{SpO}_{2}$ left skewed distribution at different altitudes and ages is shown. In Figure 6 the increase in the difference between percentile $5^{\text {th }}$ and percentile $95^{\text {th }}$ as altitude increases, can be seen reflecting how the left bias is more evident as altitude increases.

The comparison of $\mathrm{SpO}_{2}$ values from the first quartile with those from the second to fourth quartiles grouped, using data from the Rojas-Camayo study, indicated statistically significant differences in all altitude/age groups analyzed (Table 7).

\section{Hemoglobin concentration measurement}

Hemoglobin $(\mathrm{Hb})$ concentration was only measured in two studies (Mattos et al., 2005 and Ramírez-Cardich et al., 2004). Oxygen carrying capacity was not calculated in any of the studies.

\section{DISCUSSION}

To the best of our knowledge, this is the first systematic review to examine the influence of high altitude on $\mathrm{SpO}_{2}$ across childhood from 0 to 19 years of age. It builds on data published by Subhi (Subhi et al., 2009), which was limited to six studies above 2500 masl (rather than the 19 included here), and to pre-adolescent children. Furthermore, we included data on infants when feeding and report key differences between wake and sleep states. 
Data provided by this review show that $\mathrm{SpO}_{2}$ at high altitudes increases through childhood; this phenomenon was highlighted by Beall (Beall 2000) who reported that at altitudes between 3800-4200 masl, $\mathrm{SpO}_{2}$ peak values were attained by 11 years of age and were $7 \%$ higher than values in young infants. The $\mathrm{SpO}_{2}$ improvement with age can be viewed as a marker of physiological adaptation or "SpO 2 maturation" (Hill et al., 2016) ${ }^{\mathrm{b}}$; interestingly $\mathrm{SpO}_{2}$ maturation is not a phenomenon exclusive to high altitude and is also seen at sea level (Schulter et al., 2001). In addition, the present review shows that inter-individual variability in $\mathrm{SpO}_{2}$ is higher at younger ages (Figures 3, 4 and 6). This point was also noted by Beall (Beall 2000) and has been observed in subsequent studies (Duenas-Meza et al., 2015). This interindividual variation increases with altitude and is more marked during sleep (Figures 3, 4 and 6) (Duenas-Meza et al., 2015; Hill et al., 2016; Ucrós et al., 2015; Ucrós S et al., 2017) and during feeding in young infants (Torres et al., 1999; Niermeyer et al., 1993; Niermeyer et al., 1995). In consequence at altitudes $>2500$ masl, $\mathrm{SpO}_{2}$ treatment thresholds may change depending on sleep-wake or feeding status, especially in young infants.

The lower $\mathrm{SpO}_{2}$ values during sleep are normal in children, even at sea-level (MacLean et al., 2015'), and could be related with drops in respiratory rate and functional residual capacity, as well as, and increase in upper airway resistance (Marcus 2001). What emerges from the present review is that the $\mathrm{SpO}_{2}$ gap between wake and sleep stages is notable at high altitude. The explanation for lower $\mathrm{SpO}_{2}$ values during feeding in infants is less certain; a recent study in infants, aged 2 weeks-3 months with cardiac disease, showed significant desaturation (mean -2.8\%) 
during feeding but no drop in a healthy age-similar control group (Miranda et al., 2019). The lower baseline $\mathrm{SpO}_{2}$ values in the infants with cardiac disease are similar to those seen in Andean infants at the threshold of high altitude; this suggests that minor perturbations in ventilation associated with infant feeding may become critical when baseline $\mathrm{SpO}_{2}$ is lowered. As it is known, from the $\mathrm{O}_{2}$ dissociation curve, at high altitude mild changes in $\mathrm{P}_{\mathrm{a}} \mathrm{O}_{2}$ induce significant $\mathrm{SpO}_{2}$ drops (Chernick $\mathrm{V}$, West JB., 1990).

In relation with lower $\mathrm{SpO}_{2}$ values during sleep in children, it is known at sea level, that normal sleep onset prompts a fall in respiratory rate, functional residual capacity and an increase in upper airway resistance (Marcus 2001), and that small decrements in oxygen saturation (e.g 1-2\%) are acceptable (MacLean et al., 2015¹). Regarding with differences by sex, it is been found in adults aged 30 to 40 years at high altitude, higher $\mathrm{SpO}_{2}$ levels in females than in males (Beall 2000), but similar findings are not evidenced in the pediatric literature (Huicho L et al, 2001).

An interesting question is why $\mathrm{SpO}_{2}$ maturation occurs. It could be hypothesized that since periodic breathing $(\mathrm{PB})$ is much more important at high altitude during the first months of life (Duenas-Meza et al., 2015; Ucrós et al., 2015, Ucrós et al., 2017), there could be a link between $\mathrm{SpO}_{2}$ increase and decrease in PB with age. We found 2 studies in infants which explored this possible association. The first was carried out by Parkins et al, who exposed 34 healthy infants to a $15 \%$ oxygen environment during a mean of 6.3 hours sleep, and measured oxygen saturation, frequency of isolated and periodic apnea, and frequency of desaturation (Parkins et al., 1998). In the later published by Ucrós et al, oxygen saturation, PB and apnea indexes were 
measured during a mean of 4.1 hours sleep at 2560 masl, in infants aged between 1 and 4 months (Ucrós et al., 2015). Neither study found an association between mean $\mathrm{SpO}_{2}$ and PB. Similarly, studies carried out in adults have not found this correlation (Insalaco et al., 2012; Salvaggio et al., 1998; Ainslie et al., 2013). A second hypothesis could be related to possible changes in ventilation across childhood at high altitude, nevertheless studies undertaken by Beall on different populations do not support this theoretical mechanism; this research showed that Tibetans were more hypoxic than Aymara, despite a higher resting ventilation and hypoxic ventilatory responses (Beall et al., 1997). A third mechanism, and probably the most plausible hypothesis, is that as pulmonary pressure falls through childhood, the $\mathrm{SpO}_{2}$ gradually increases (Penaloza and Arias-Stella., 2007). The question that would then remain is why pulmonary pressure shows such behavior in children living at high altitude.

In six studies, data explicitly demonstrated a non-normal $\mathrm{SpO}_{2}$ left skewed distribution, meaning significant inter-individual differences in $\mathrm{SpO}_{2}$ at a same age and altitude. This phenomena was also noted when data from an early study published in 1963 were reanalyzed; in this research oxygen saturation was measured in blood in children living around 4,400 masl (Sime et al 1963) (Figure 5). The striking feature of a left skewed $\mathrm{SpO}_{2}$ distribution has been found consistently across different altitudes, ages and sleep versus wake states. At high altitude, the $\mathrm{SpO}_{2}$ non-normal statistical distribution delivers a parabolic curve, which has to be differentiated from the sinusoidal oxygen dissociation curve related with the capacity 
of hemoglobin to carry oxygen. This concept is illustrated in Figure 7 (Chernick V, West JB., 1990; Peñaloza D, Arias-Stella J. 2007).

We speculate that children with low steady state oxygen saturation measures during health may be at increased risk of later life chronic mountain sickness (CMS) in its different forms. These include CMS with altitude polycythemia or Monge's disease (Villafuerte et al 2016); high-altitude heart disease (HAHD) or high-altitude pulmonary hypertension which occurs without polycythemia (Aldashev et al., 2002; Kojonazorov et al 2007; Ge and Helun 2001; Reeves and Grover 2005; Xu and Jing 2009); and mixed CMS, which includes both excessive polycythemia and pulmonary hypertension-related HAHD ( $\mathrm{Ge}$ and Helun 2001). These different kinds of progressive, life-limiting conditions, affect $5-10 \%$ of high-altitude residents in the first category (Leon-Velarde 2005), and 5 to $18 \%$ in the second one (Mirrakhimov and Strohl 2016). To the best of our knowledge childhood predictors of CMS have not been reported. The etiology of this condition is likely to be multi-factorial including genetically determined differences in erythropoiesis regulation, as demonstrated by Stobdan et al, who identified novel genes involved in high altitude adaptation in the Andes (Stobdan et al, 2017); alterations in ventilatory responses to hypoxia (Villafuerte et al, 2016); hypoxia gene expressions related with CMS (Stobdan et al, 2017; Xing G et al., 2008) and levels of mediators related with lung vascular reactivity (Aldashev et al.,2002; Kojonazarov et al., 2012). Longitudinal studies of $\mathrm{SpO}_{2}$ across childhood would be of value in this context.

The present study has several limitations. First, different oximeter devices and/or protocols for measuring $\mathrm{SpO}_{2}$ were used across the different studies, and in most 
studies, we do not have information relating to important equipment settings such as sampling rate and averaging time (Hill et al., 2016). ${ }^{c}$ Secondly, the data available across the publications used different approaches for central tendency measures, with some studies reporting means while others reported medians. Similarly, in relation to dispersion, different measures were used including percentiles, standard deviation, confidence intervals and interquartile ranges. Thirdly, ethnic background is a key influence on high altitude adaptation and data presented here represent populations with different adaptive mechanisms. Fourth, only two studies measured $\mathrm{Hb}$ concentration levels. Importantly, $\mathrm{SpO}_{2}$ alone is a limited indicator of oxygen delivery to the tissues, especially in the setting of polycythemia.

However, this review also has notable strengths. In total 20 studies were analyzed which included $8347 \mathrm{SpO}_{2}$ data; furthermore, the quality assessment of most studies was high with a low risk of bias. Importantly, diurnal-nocturnal variation highlighted from sleep data cannot be accounted for by hemoglobin concentration fluctuations, suggesting genuinely compromised adaptation to high altitude in some children that may have implications for later life chronic mountain sickness vulnerability. Finally the data synthesized in this review offer interesting insights into the concept of $\mathrm{SpO}_{2}$ maturation at high altitude.

The need for international reference data on ranges of $\mathrm{SpO}_{2}$ across childhood at high altitude remains pressing. Future studies should use standardized oximetry protocols (uniform devices and settings) and standardized reporting of data to confidently establish such reference data in healthy children to support clinical decision-making. In the meantime, the data synthesized in this review provides a 
preliminary guide for clinicians managing children with cardio-respiratory disorders at high altitude.

\section{CONCLUSIONS}

At high altitude mean/medians $\mathrm{SpO}_{2}$ improves in infants and children with aging; a significant gap between wake and sleep states is seen in the first months of life, which narrows, as the infant gets older; $\mathrm{SpO}_{2}$ dispersion at high altitude is wider at younger ages; at high altitude $\mathrm{SpO}_{2}$ shows a non-normal distribution skewed to the left, this bias becomes more evident as altitude increases, at younger ages and during sleep. $\mathrm{SpO}_{2}$ has inter-individual differences at a same given age and altitude, being significantly lower in 1 out of 4 children. Collaborative studies using similar oximeters/protocols for measuring $\mathrm{SpO}_{2}$ at different altitudes in healthy children across high-altitude geographical regions are urgently needed.

\section{DISCLOSURES}

The authors have no conflict of interests to declare.

\section{ACKNOWLEDGMENTS}

The authors thank Mr. Gerardo Ardila, Statician MSc, of the Research Department of the Fundación Santa Fe de Bogotá, for his valuable help in the construction of graphics and statistical analysis, Doctor Jose Rojas-Camayo of the Instituto de Investigaciones de la Altura, Universidad Peruana Cayetano Heredia, Lima, Peru, for providing raw data from the publication "Reference values for oxygen saturation from sea level to the highest human habitation in the Andes in acclimatised persons" (Rojas-Camayo et al., 2018) and Professor Romola Bucks of the University of 
Western Australia for providing raw data from the DeSat study (Hill et al., 2016a; Hill et al., 2016 ${ }^{\text {b) }}$.

\section{REFERENCES}

1- Ainslie PN, Lucas SJ, Burgess KR (2013). Breathing and sleep at high altitude. Respir Physiol Neurobiol 188(3):233-56.

2- Aldashev AA, Sarybaev AS, Sydykov AS, Kalmyrzaev BB, Kim EV, Mamanova LB, Maripov R, Kojonazarov BK, Mirrakhimov MM, Wilkins MR, Morrell NW (2002). Characterization of high-altitude pulmonary hypertension in the Kyrgyz: association with angiotensin-converting enzyme genotype. Am J Respir Crit Care Med 166(10):1396-402.

3- Alduncin J, Grañana N, Follett F, Musante G, Milberg F, Vogler G y Rocca Rivarola M (2005). Problemas respiratorios durante el sueño en lactantes nativos del altiplano argentino. Arch Argent Pediatr 103(1):14-22.

4- Beall CM (2000). Oxygen saturation increases during childhood and decreases during adulthood among high altitude native Tibetians residing at 3,800-4,200m. High Alt Med Biol 1(1):25-32.

5- Beall CM, Strohl KP, Blangero J, Williams-Blangero S, Almasy LA, Decker MJ, Worthman CM, Goldstein MC, Vargas E, Villena M, Soria R, Alarcon AM, Gonzales C (1997). Ventilation and hypoxic ventilatory response of Tibetan and Aymara high altitude natives. Am J Phys Anthropol 104(4):427-47.

6- Chernick V, West JB (1990). The Functional Basis of Respiratory Disease. In: Kendig's Disorders of the Respiratory Tract in Children. Saunders-Elsevier Ed. pp 52.

7- Duenas-Meza E, Bazurto MA, Gozal D, González-García M, Durán-Cantolla J, Torres-Duque CA (2015). Overnight polysomnographic characteristics and oxygen saturation of healthy infants, 1 to 18 months of age, born and residing at high altitude (2,640 meters). Chest 148(1):120-7. 
8- Gamponia MJ, Babaali H, Yugar F, Gilman RH (1998). Reference values for pulse oximetry at high altitude. Arch Dis Child 78:461-5.

9- Ge RL, Helun G (2001). Current concept of chronic mountain sickness: pulmonary hypertension-related high-altitude heart disease. Wilderness Environ Med 12(3):190-4.

10- Gonzáles GF, Salirrosas A (2005). Arterial oxygen saturation in healthy newborns delivered at term in Cerro de Pasco (4340 m) and Lima (150 m). Reprod Biol Endocrinol 3:46.

11- Hill CM, ${ }^{\text {a }}$ Carroll A, Dimitriou D, Gavlak J, Heathcote K, L'Esperance V, Baya A, Webster R, Pushpanathan M, Bucks RS (2016). Polysomnography in Bolivian Children Native to High Altitude Compared to Children Native to Low Altitude. Sleep 39 (12):2149-2155.

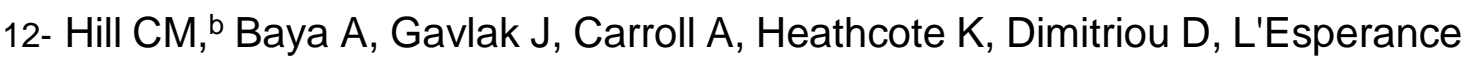
V, Webster R, Holloway J, Virues-Ortega J, Kirkham FJ, Bucks RS, Hogan AM (2016). Adaptation to Life in the High Andes: Nocturnal Oxyhemoglobin Saturation in Early Development. Sleep 39(5):1001-8.

13- Hill CM, ${ }^{c}$ Evans HJ (2016). The investigation of sleep disordered breathing: seeing through a glass darkly. Archives of Disease in Childhood 101(12):1082-1083.

14- Huicho L, Pawson IG, León-Velarde F, Rivera-Chira M, Pacheco A, Muro M, Silva J (2001). Oxygen saturation and heart rate in healthy school children and adolescents living at high altitude. Am J Hum Biol 13(6):761-70.

15- Insalaco G, Romano S, Salvaggio A, Pomidori L, Mandolesi G, Cogo A (2012). Periodic breathing, arterial oxyhemoglobin saturation, and heart rate during sleep at high altitude. High Alt Med Biol 13(4):258-62.

16- Kojonazarov BK, Imanov BZ, Amatov TA, Mirrakhimov MM, Naeije R, Wilkins MR, Aldashev AA. (2007). Noninvasive and invasive evaluation of pulmonary arterial pressure in highlanders. Eur Respir J 29(2):352-6.

17- Kojonazarov B, Isakova J, Imanov B, Sovkhozova N, Sooronbaev T, Ishizaki T, Aldashev AA. (2012). Bosentan reduces pulmonary artery pressure in high altitude residents. High Alt Med Biol 13(3):217-23. 
18- Lazzerini M, Sonego M, Pellegrin MC (2015). Hypoxaemia as a Mortality Risk Factor in Acute Lower Respiratory Infections in Children in Low and MiddleIncome Countries: Systematic Review and Meta-Analysis. PLoS One 10(9):e0136166.

19- Leon-Velarde F, Maggiorini M, Reeves JT, Aldashev A, Asmus I, Bernardi L, Ge RL, Hackett P, Kobayashi T, Moore LG, Penaloza D, Richalet JP, Roach R, WuT, Vargas E, Zubieta-Castillo G, and Zubieta-Calleja G (2005).Consensus statement on chronic and subacute high altitude diseases. High Alt Med Biol 6:147-157.

20- Lozano JM, Duque OR, Buitrago T, Behaine S (1992). Pulse oximetry reference values at high altitude. Arch Dis Child 67:299-301.

21- MacLean JE, Fitzgerald DA, Waters KA (2015). Developmental changes in sleep and breathing across infancy and childhood. Paediatr Respir Rev 6(4):276-84.

22- Marcus CL (2001). Sleep-disordered breathing in children. Am J Respir Crit Care Med 164(1):16-30.

23- Mattos P, Caballero A Urquieta, Bartos A (2005). Gasometría, hematocrito y oximetría de pulso en recién nacidos a 3.600 metros sobre el nivel del mar. Rev Soc Bol Ped 44 (3): 158-60.

24- Miranda VSG, Souza PC, Etges CL, Barbosa LR (2019). Cardiorespiratory parameters in infants cardiopathy: variations during feeding. Codas 7;31(2):e20180153.

25- Mirrakhimov AE, Strohl KP (2016). High-altitude Pulmonary Hypertension: an Update on Disease Pathogenesis and Management. Open Cardiovasc Med J 8; 10:19-27.

26- Moore LG (2001). Human genetic adaptation to high altitude. High Alt Med Biol 2(2):257-79.

27- Mower WR, Sachs C, Nicklin EL and Baraff LJ (1997). Pulse Oximetry as a Fifth Pediatric Vital Sign. Pediatrics 99:681-686.

28- Nicholas R, Yaron M, Reeves J (1993). Oxygen saturation in children living at moderate altitude. J Am Board Fam Pract 6:452-6. 
29- Niermeyer S, Shaffer EM, Thilo E, Corbin C, Moore LG (1993). Arterial oxygenation and pulmonary arterial pressure in healthy neonates and infants at high altitude. J Pediatr 123:767-72.

30- Niermeyer S, Yang P, Shanmina, Drolkar, Zhuang J, Moore LG (1995). Arterial oxygen saturation in Tibetan and Han infants born in Lhasa, Tibet. $\mathrm{N}$ Engl J Med 333(19):1248-52.

31- Parkins KJ, Poets CF, O'Brien LM, Stebbens VA, Southall DP (1998). Effect of exposure to $15 \%$ oxygen on breathing patterns and oxygen saturation in infants: interventional study. BMJ Circulation 316(7135):887-91.

32- Penaloza D, Arias-Stella J (2007). The heart and pulmonary circulation at high altitudes: healthy highlanders and chronic mountain sickness. Circulation 6; 115(9):1132-46.

33- Ramírez-Cardich ME, Saito M, Gilman RH, Escate LE, Strouse JJ, Kabrhel C, Johnson C, Galchen R, Bautista CT (2004). Effect of maternal anemia at high altitude on infant hematocrit and oxygenation. Am J Trop Med Hyg 70(4):420-4.

34- Reeves JT, Grover RF (2005). Insights by Peruvian scientists into the pathogenesis of human chronic hypoxic pulmonary hypertension. J Appl Physiol 98(1):384-9.

35- Rojas-Camayo J, Mejia CR, Callacondo D, Dawson JA, Posso M, Galvan CA, Davila-Arango N, Bravo EA, Loescher VY, Padilla-Deza MM, RojasValero N, Velasquez-Chavez G, Clemente J, Alva-Lozada G, QuispeMauricio A, Bardalez S, Subhi R (2018). Reference values for oxygen saturation from sea level to the highest human habitation in the Andes in acclimatised persons. Thorax 73(8):776-778.

36- Salvaggio A, Insalaco G, Marrone O, Romano S, Braghiroli A, Lanfranchi P, Patruno V, Donner CF, Bonsignore G (1998). Effects of high-altitude periodic breathing on sleep and arterial oxyhaemoglobin saturation. Eur Respir $\mathrm{J}$ 12(2):408-13.

37- Schlüter B, Buschatz D, Trowitzsch E (2001). Polysomnographic Reference Curves for the First and Second Year of Life. Somnologie 5: 3-16. 
38- Schult S, Canelo-Aybar C (2011). Oxygen saturation in healthy children aged 5 to 16 years residing in Huayllay, Peru at $4340 \mathrm{~m}$. High Alt Med Biol 12(1):89-92.

39- Severinghaus JW (2007). Takuo Aoyagi: discovery of pulse oximetry. Anesth Analg. 105:S1-4.

40- Sime F, Banchero N, Penaloza D, Gamboa R, Cruz J, Marticorena E (1963). Pulmonary hypertension in children born and living at high altitudes. Am $\mathrm{J}$ Cardiol 11:143-9.

41- Shrestha S, Shrestha S, Shrestha L, Bhandary N (2012). Oxygen saturation of hemoglobin in healthy children of 2-14 years at high altitude in Nepal. Kathmandu Univ Med J (KUMJ) 10(37):40-3.

42- Sime F, Monge C, and Whittembury J (1975). Age as a cause of chronic mountain sickness (Monge's disease). Int J Biometeorol 19:93-98.

43- Stobdan T, Akbari A, Azad P, Zhou D, Poulsen O, Appenzeller O, Gonzales GF, Telenti A, Wong EHM, Saini S, Kirkness EF, Venter JC, Bafna V, Haddad GG (2017). New Insights into the Genetic Basis of Monge's Disease and Adaptation to High-Altitude. Mol Biol Evol 1;34(12):3154-3168.

44- Subhi R, Smith K, Duke T (2009). When should oxygen be given to children at high altitude? A systematic review to define altitude-specific hypoxaemia. Arch Dis Child 94(1):6-10.

45- Torres Y, Osorio L, Ramos N (1999). Medición de los valores de oximetría de pulso durante sueño, vigilia y succión en neonatos sanos en Bogotá (2640 metros de altura sobre el nivel del mar). Avances Pediátricos 1:2-8.

46- Ucrós S, Granados C, Parejo K, Guillén F, Ortega F, Restrepo S, Gil F, Guillén M (2015). Oxygen saturation, periodic breathing and apnea during sleep in infants 1 to 4 month old living at 2,560 meters above sea level. Arch Argent Pediatr 113(4):341-344.

47- Ucrós S, Granados C, Parejo K, Ortega F, Guillén F, Restrepo S, Gil F, Guillén M (2017). Oxygen saturation, periodic breathing, and sleep apnea in infants aged 1-4 months old living at 3200 meters above sea level. Arch Argent Pediatr 115(1):54-57. 
48- Villafuerte FC, Corante N (2016). Chronic Mountain Sickness: Clinical Aspects, Etiology, Management, and Treatment. High Alt Med Biol 17(2):6169.

49- Weitz CA, Garruto RM (2007). A comparative analysis of arterial oxygen saturation among Tibetans and Han born and raised at high altitude. High Alt Med Biol 8(1):13-26.

50- Wells GA, Shea B, O'Connell D, Peterson J, Welch V et al (2011). The Newcastle-Ottawa Scale (NOS) for assessing the quality of nonrandomized studies in meta-analysis. Available: www.ohri.ca/programs/clinicalepidemiology/oxford.asp. 2011. Consulted April 1, 2019.

51- Xing G, Qualls C, Huicho L, Rivera-Ch M, Stobdan T, Slessarev M, Prisman E, Ito $S$, Wu H, Norboo A, Dolma D, Kunzang M, Norboo T, Gamboa JL, Claydon VE, Fisher J, Zenebe G, Gebremedhin A, Hainsworth R, Verma A, Appenzeller $O$ (2008). Adaptation and mal adaptation to ambient hypoxia; Andean, Ethiopian and Himalayan patterns. PLoS One 4;3(6):e2342.

52- Xu XQ and Jing ZC (2009). High-altitude pulmonary hypertension. Eur Respir Rev 18(111):13-7. 
Table 1. Pulse oximetry device used and duration of $\mathrm{SpO}_{2}$ measurement

\begin{tabular}{|c|c|c|}
\hline Study/ref & Oximeter type & Duration of recording \\
\hline Alducín $2005^{3}$ & NONIN & $\begin{array}{l}\text { No data during wakefulness. Overnight for } \\
\text { nocturnal measurement (3:25 to } 5: 45 \text { hours). }\end{array}$ \\
\hline Beall $2000^{4}$ & CRITICARE M 503 & $\begin{array}{l}\text { Six observations were recorded and their } \\
\text { average was used as the individual's } \mathrm{SpO}_{2} \text {. }\end{array}$ \\
\hline Dueñas-Meza 20157 & MASSIMO RAD 8 & $\begin{array}{l}\text { All the time during wakefulness and sleep } \\
\text { during polysomnography study up to } 10 \\
\text { hours. Minimum time and mean time: no } \\
\text { data. }\end{array}$ \\
\hline Gamponia $1998^{8}$ & NELLCOR N 10 & At least 10 seconds. \\
\hline Hill $2016^{11}$ & NONIN, PLYMOUTH, (MN) & $\begin{array}{l}\text { Sampling rate and data averaged } \\
\text { over } 4 \text { successive pulse beats. }\end{array}$ \\
\hline Hill $2016^{12}$ & MASIMO RADICAL & $\begin{array}{l}\text { At least } 3 \text { minutes for diurnal measurement. } \\
\text { Overnight for nocturnal measurement } \\
\text { (minimum } 5 \text { hours of artefact free data). }\end{array}$ \\
\hline Huicho $2001^{14}$ & NELLCOR & $\begin{array}{c}\text { Values were recorded after machine } \\
\text { stabilization. When values oscillated, the } \\
\text { average of three consecutive readings was } \\
\text { used. }\end{array}$ \\
\hline Lozano $1992^{20}$ & NELLCOR N 10 & $\begin{array}{c}\text { At least } 10 \text { seconds. All readings were } \\
\text { duplicated. }\end{array}$ \\
\hline Mattos $2005^{24}$ & NO DATA & No data \\
\hline Nicholas $1993^{28}$ & NEONATAL FLEX IT & At least 2 minutes. \\
\hline Niermeyer $1993^{29}$ & $\mathrm{BIOX} 3700 \mathrm{BIO}$ & $\begin{array}{l}\text { Value was considered acceptable when the } \\
\text { electrocardiographically measured heart rate } \\
\text { was within } 5 \text { beats/min of the oximetry- } \\
\text { determined pulse rate and the pulse } \\
\text { waveform displayed on the oximeter was } \\
\text { clear and full. } \\
\end{array}$ \\
\hline Niermeyer $1995^{30}$ & $\mathrm{BIOX} 3740$ & 1-minute intervals for a total of 10 minutes. \\
\hline Ramírez-Cardich $2004^{33}$ & NELLCOR N 20 & $\begin{array}{c}\text { One-minute intervals for a total of } 10 \\
\text { minutes. }\end{array}$ \\
\hline Rojas-Camayo $2018^{35}$ & NELLCOR 560 & $\begin{array}{l}\text { Every } 10 \mathrm{~s} \text { for a total of six measurements } \\
\text { and the average was the final value. }\end{array}$ \\
\hline Schult $^{38}$ & DEVON MEDICAL 300C-1 & More than $10 \mathrm{sec}$ \\
\hline Shrestha $2012^{41}$ & CMS- 50DL & $\begin{array}{l}\text { Several readings until a consistent value } \\
\text { was displayed }\end{array}$ \\
\hline Torres $1999^{45}$ & MASIMO SET & $\begin{array}{c}\text { Two registers, one minute each one and } \\
\text { average was the final value. }\end{array}$ \\
\hline Ucrós $2015^{46}$ & NONIN M 8008J & $\begin{array}{l}\text { All the time during overnight } \\
\text { polysomnography study. Minimum time } 180 \\
\text { min -Mean time } 250 \text { min. }\end{array}$ \\
\hline Ucrós $2017^{47}$ & NONIN M 8008J & $\begin{array}{l}\text { All the time during overnight } \\
\text { polysomnography study. Minimum time } 180 \\
\text { min -Mean time } 250 \text { min. }\end{array}$ \\
\hline Weitz $2007^{49}$ & NONIN 8500 & Between 5 and 10 minutes. \\
\hline
\end{tabular}


Table 2. Resting $\mathrm{SpO} 2$ in high altitude resident Andean children during the wake state by age group and altitude (ordered from lower to higher altitude)

\begin{tabular}{|c|c|c|c|c|c|c|}
\hline Author /year & Country & $\begin{array}{l}\text { Altitude } \\
\text { (masl) }\end{array}$ & Age range & $\mathbf{n}$ & $\begin{array}{c}\% \mathrm{SpO}_{2} \\
\text { median/mean }\end{array}$ & $\begin{array}{l}\mathrm{SpO}_{2} \text { dispersion } \\
\text { measurements }\end{array}$ \\
\hline Rojas-Camayo/201835 & Perú & 2500 & $1-5 \mathrm{yrs}$ & 87 & 96.0 (median) & p5 $5^{\text {th }} 93.0 \%, p 95^{\text {th }} 98.0 \%$ \\
\hline Rojas-Camayo/201835 & Perú & 2500 & $5-17$ yrs & 234 & 97.0 (median) & p5 $5^{\text {th }} 94.0 \%, p 95^{\text {th }} 99.0 \%$ \\
\hline Hill/2016 & Bolivia & 2500 & $4-10$ yrs & 9 & 94.0 (median) & IQR 1\% \\
\hline Torres /199945 & Colombia & 2640 & $1-30$ days & 300 & 95.0 (median) & p5 $5^{\text {th }} 90.5 \%, p 95^{\text {th }} 98.8 \%$ \\
\hline Lozano /199220 & Colombia & 2640 & $1-3 \mathrm{mo}$ & 35 & 95.3 (median) & $95 \% \mathrm{Cl}$ [90.5\%-98.8\%] \\
\hline Dueñas-Meza/20157 & Colombia & 2640 & $1 \pm 0.3 \mathrm{mo}$ & 106 & 92.5 (median) & $\mathrm{p}^{\text {th }} 88.0 \%, \mathrm{p} 95^{\text {th }} 96.0 \%$ \\
\hline Dueñas-Meza /20157 & Colombia & 2640 & $3.6 \pm 0.5 \mathrm{mo}$ & 89 & 93.0 (median) & $p 5^{\text {th }} 88.0 \%, p 95^{\text {th }} 96.0 \%$ \\
\hline Dueñas-Meza /20157 & Colombia & 2640 & $6.3 \pm 0.8 \mathrm{mo}$ & 89 & 93.0 (median) & $p 5^{\text {th }} 90.0 \%, p 95^{\text {th }} 97.0 \%$ \\
\hline Lozano/1992 & Colombia & 2640 & $7-12 \mathrm{mo}$ & 23 & 93.4 (median) & 95\%Cl [92.4\%-94.4\%] \\
\hline Dueñas-Meza/20157 & Colombia & 2640 & $13.2 \pm 1.9 \mathrm{mo}$ & 25 & 94.0 (median) & $p 5^{\text {th }} 91.0 \%, p 95^{\text {th }} 96.0 \%$ \\
\hline Rojas-Camayo/201835 & Perú & 2880 & $1-5 \mathrm{yrs}$ & 95 & 95.0 (median) & p5 $5^{\text {th }} 92.0 \%, p 95^{\text {th }} 98.0 \%$ \\
\hline Rojas-Camayo/201835 & Perú & 2880 & $5-17$ yrs & 122 & 96.0 (median) & $p 5^{\text {th }} 92.0 \%, p 95^{\text {th }} 98.0 \%$ \\
\hline Rojas-Camayo/201835 & Perú & 3250 & $1-5 \mathrm{yrs}$ & 140 & 93.0 (median) & $p 5^{\text {th }} 89.0 \%, p 95^{\text {th }} 95.0 \%$ \\
\hline Rojas-Camayo/201835 & Perú & 3250 & $6-17$ yrs & 181 & 94.0 (median) & $p 5^{\text {th }} 91.0 \%, p 95^{\text {th }} 97.0 \%$ \\
\hline Mattos/2005 21 & Bolivia & 3600 & $1-2 \mathrm{wk}$ & 60 & 85.3 (mean) & \pm 1 SD $10.5 \%$ \\
\hline Rojas-Camayo/201835 & Perú & 3600 & $1-5 \mathrm{yrs}$ & 30 & 93.0 (median) & $p 5^{\text {th }} 87.0 \%, p 95^{\text {th }} 95.0 \%$ \\
\hline Rojas-Camayo/201835 & Perú & 3600 & $6-17 \mathrm{yrs}$ & 117 & 93.0 (median) & p5 $5^{\text {th }} 90 \%, p 95^{\text {th }} 95.0 \%$ \\
\hline Hill/2016 & Bolivia & 3700 & $6-12 \mathrm{mo}$ & 7 & 94.0 (median) & IQR 2\% \\
\hline Hill/2016 & Bolivia & 3700 & $4-10$ yrs & 18 & 94.0 (median) & IQR 1\% \\
\hline Hill/2016 & Bolivia & 3700 & 13-17 yrs & 7 & 94.0 (median) & IQR 2\% \\
\hline Ramírez-Cardich/200433 & Perú & 3750 & $2 \mathrm{wk}$ & 30 & 91.0 (mean) & No data \\
\hline Ramírez-Cardich /200433 & Perú & 3750 & $1 \mathrm{mo}$ & 33 & 92.0 (mean) & No data \\
\hline
\end{tabular}




\begin{tabular}{|c|c|c|c|c|c|c|}
\hline Ramírez-Cardich/200433 & Perú & 3750 & $2 \mathrm{mo}$ & 32 & 92.0 (mean) & No data \\
\hline Ramírez-Cardich/2004 ${ }^{33}$ & Perú & 3750 & $3 \mathrm{mo}$ & 33 & 92.0 (mean) & No data \\
\hline Ramírez-Cardich /200433 & Perú & 3750 & $4 \mathrm{mo}$ & 30 & 92.0 (mean) & No data \\
\hline Alducín/2005³ & Argentina & 3775 & $7-31 w k$ & 12 & 86.0 (mean) & \pm 1 SD $2.6 \%$ \\
\hline Ramírez-Cardich/2004 ${ }^{33}$ & Perú & 3750 & 2 wk & 30 & 91.0 (mean) & No data \\
\hline Ramírez-Cardich /200433 & Perú & 3750 & $1 \mathrm{mo}$ & 33 & 92.0 (mean) & No data \\
\hline Ramírez-Cardich/2004 ${ }^{33}$ & Perú & 3750 & $2 \mathrm{mo}$ & 32 & 92.0 (mean) & No data \\
\hline Ramírez-Cardich/2004 ${ }^{33}$ & Perú & 3750 & $3 \mathrm{mo}$ & 33 & 92.0 (mean) & No data \\
\hline Ramírez-Cardich /200433 & Perú & 3750 & $4 \mathrm{mo}$ & 30 & 92.0 (mean) & No data \\
\hline Gamponia/1998 & Bolivia & 4018 & $1-60 \mathrm{mo}$ & 128 & 88.3(median) & $95 \% \mathrm{Cl}[87.8 \%-88.1 \%]$ \\
\hline Rojas-Camayo/2018 & Perú & 4338 & $1-5 \mathrm{yrs}$ & 47 & 86.0 (median) & $p 5^{\text {th }} 82.0 \%, p 95^{\text {th }} 90.0 \%$ \\
\hline Rojas-Camayo/201835 & Perú & 4338 & $6-17$ yrs & 126 & 88.0 (median) & p5 $5^{\text {th }} 82.0 \%, p 95^{\text {th }} 92.0 \%$ \\
\hline Schult/201138 & Perú & 4340 & $5-6$ yrs & 78 & 83.8 (mean) & \pm 2 SD $10 \%$ \\
\hline Schult/201138 & Perú & 4340 & $7-8$ yrs & 43 & 83.7 (mean) & \pm 2 SD $8.4 \%$ \\
\hline Schult/201138 & Perú & 4340 & $9-10$ yrs & 108 & 84.7 (mean) & \pm 2 SD $5.4 \%$ \\
\hline Schult/201138 & Perú & 4340 & $11-12$ yrs & 40 & 86.5 (mean) & \pm 2 SD $8.6 \%$ \\
\hline Schult/201138 & Perú & 4340 & 13-14 yrs & 54 & 88.1 (mean) & \pm 2 SD $7.0 \%$ \\
\hline Schult/201138 & Perú & 4340 & $15-16$ yrs & 63 & 88.4 (mean) & \pm 2SD $6.6 \%$ \\
\hline Rojas-Camayo/2018 35 & Perú & 4500 & $1-5 \mathrm{yrs}$ & 36 & 85.0 (median) & p5 $5^{\text {th }} 78.0 \%, p 95^{\text {th }} 90.0 \%$ \\
\hline Rojas-Camayo/2018 & Perú & 4500 & $6-17$ yrs & 121 & 85.0 (median) & p5 $5^{\text {th }} 79.0 \%, p 95^{\text {th }} 90.0 \%$ \\
\hline Rojas-Camayo/2018 35 & Perú & 4715 & $1-5 \mathrm{yrs}$ & 28 & 83.0 (median) & p5 $5^{\text {th }} 78.0 \%, p 95^{\text {th }} 89.0 \%$ \\
\hline Rojas-Camayo/2018 & Perú & 4715 & $6-17$ yrs & 133 & 86.0 (median) & p5 $5^{\text {th }} 79.0 \%, p 95^{\text {th }} 92.0 \%$ \\
\hline Rojas-Camayo/2018 & Perú & 5100 & $1-5 \mathrm{yrs}$ & 74 & 80.0 (median) & p5 $5^{\text {th }} 73.0 \%, p 95^{\text {th }} 85.0 \%$ \\
\hline Rojas-Camayo/2018 & Perú & 5100 & $6-17 \mathrm{yrs}$ & 168 & 81.0 (median) & $p 5^{\text {th }} 75.0 \%, p 95^{\text {th }} 86.0 \%$ \\
\hline
\end{tabular}


Table 3. Resting $\mathrm{SpO}_{2}$ in high altitude resident Himalayan children during the wake state by age

\begin{tabular}{|c|c|c|c|c|c|c|}
\hline Author /year & Country & $\begin{array}{c}\text { Altitude } \\
\text { (masl) }\end{array}$ & Age range & $\mathbf{N}$ & $\begin{array}{c}\mathrm{OSpO}_{2} \\
\text { mean }\end{array}$ & $\begin{array}{l}\mathrm{SpO}_{2} \text { dispersion } \\
\text { measurements }\end{array}$ \\
\hline Shresta/2012 41 & Nepal & 2700 & $2-14$ yrs & 56 & 95.0 & \pm 1 SD $1.3 \%$ \\
\hline Shresta/201241 & Nepal & 2800 & $2-14$ yrs & 22 & 95.0 & \pm 1 SD $1.2 \%$ \\
\hline Weitz/200749 & China & 3200 & $5-9$ yrs & 157 & 90.8 & \pm 1 SD $3.9 \%$ \\
\hline Wetiz/200749 & China & 3200 & $10-14$ yrs & 172 & 90. & \pm 1 SD $3.2 \%$ \\
\hline Wetiz/200749 & China & 3200 & $15-19$ yrs & 148 & 91.3 & \pm 1 SD $3.0 \%$ \\
\hline Shresta/2012 41 & Nepal & 3550 & $2-14$ yrs & 19 & 91.0 & \pm 1 SD $1.7 \%$ \\
\hline Niermeyer/1995 30 & China/Han & 3658 & $1-16$ wk & 15 & 87.0 & \pm 1 SD $6.0 \%$ \\
\hline Niermeyer/1995 30 & China/Tibetan & 3658 & $1-16$ wk & 15 & 89.0 & \pm 1 SD $3.0 \%$ \\
\hline Beall/20004 & China & 3800 & $0-9$ yrs & 735 & 89.3 & No data \\
\hline Beall/20004 & China & 3800 & $10-19$ yrs & 735 & 90.9 & No data \\
\hline Shresta/201241 & Nepal & 3800 & $2-14$ yrs & 9 & 91.0 & \pm 1SD $1.2 \%$ \\
\hline Wetiz/200749 & China/Tibetan & 3800 & $5-9$ yrs & 93 & 86.5 & \pm 1 SD $3.9 \%$ \\
\hline Wetiz/200749 & China/ Han & 3800 & $5-9$ yrs & 103 & 85.5 & \pm 1 SD $4.1 \%$ \\
\hline Wetiz/200749 & China & 3800 & $10-14$ yrs & 217 & 86.6 & \pm 1 SD $3.8 \%$ \\
\hline Wetiz/200749 & China & 3800 & $15-19$ yrs & 172 & 87.6 & \pm 1 SD $2.8 \%$ \\
\hline Beall/20004 & China & 4200 & $0-9$ yrs & 294 & 85.5 & No data \\
\hline Beall/20004 & China & 4200 & $10-19$ yrs & 294 & 88.7 & No data \\
\hline Weitz/200749 & China & 4300 & $5-9$ yrs & 49 & 84.0 & \pm 1 SD $4.3 \%$ \\
\hline Weitz/200749 & China & 4300 & $10-14$ yrs & 62 & 85.0 & \pm 1 SD $3.0 \%$ \\
\hline Weitz/200749 & China & 4300 & $15-19$ yrs & 47 & 85.8 & \pm 1 SD $3.7 \%$ \\
\hline
\end{tabular}


Table 4. Resting $\mathrm{SpO}_{2}$ in high altitude resident children during the wake state by age group and

\begin{tabular}{|c|c|c|c|c|c|c|}
\hline Author /year & Country & $\begin{array}{c}\text { Altitude in } \\
\text { (masl) }\end{array}$ & Age range & $\mathbf{N}$ & $\%_{\mathbf{S p O}_{2} \text { mean }}$ & $\begin{array}{c}\mathbf{S p O}_{2} \text { dispersion } \\
\text { measurements }\end{array}$ \\
\hline Nicholas/199328 & USA & $2774-2818$ & 2 days-22 mo & 72 & 91.7 & SD $2.0 \%$ \\
\hline Niermeyer/199329 & USA & 3100 & $1 \mathrm{wk}$ & 14 & 87.8 & SD $4.8 \%$ \\
\hline Niermeyer/199329 & USA & 3100 & 2 mo & 13 & 89.9 & SD $2.4 \%$ \\
\hline Niermeyer/199329 & USA & 3100 & 4 mo & 14 & 91.1 & SD $1.7 \%$ \\
\hline
\end{tabular}

masl= meters above sea level, mo=months, wk= weeks, SD= standard deviation. 
Table 5. $\mathrm{SpO}_{2}$ in sleeping children at different ages resident at high altitudes across the world

\begin{tabular}{|c|c|c|c|c|c|c|}
\hline Author/Year & Country & $\begin{array}{c}\text { Altitude } \\
\text { (masl) }\end{array}$ & Age range & $\mathbf{N}$ & $\begin{array}{c}\% \mathrm{SpO}_{2} \\
\text { median/mean }\end{array}$ & $\begin{array}{c}\mathrm{SpO}_{2} \text { dispersion } \\
\text { measurement }\end{array}$ \\
\hline Hill/2016 ${ }^{12}$ & Bolivia & 2500 & $4-10$ yrs & 9 & 93.7 (median) & IQR $2.4 \%$ \\
\hline Ucrós/201546 & Ecuador & 2560 & $1-4 \mathrm{mo}$ & 36 & 92.0 (median) & p5 $5^{\text {th }} 86.0 \%, p 95^{\text {th }} 94.0 \%$ \\
\hline Torres/199945 & Colombia & 2640 & $1-30$ days & 300 & 95.0 (median) & p5 $5^{\text {th }} 87.5 \%, p 95^{\text {th }} 96.0 \%$ \\
\hline Dueñas-Mesa/20157 & Colombia & 2640 & $1 \pm 0.3 \mathrm{mo}$ & 106 & 92.5 (median) & p5 $5^{\text {th }} 87.5 \%, p 95^{\text {th }} 96.0 \%$ \\
\hline Dueñas-Mesa ${ }^{9} / 2015^{7}$ & Colombia & 2640 & $3.6 \pm 0.5 \mathrm{mo}$ & 89 & 93.0 (median) & p5 $5^{\text {th }} 86.0 \%, p 95^{\text {th }} 94.0 \%$ \\
\hline Dueñas-Mesa ${ }^{9} / 2015^{7}$ & Colombia & 2640 & $6.3 \pm 0.8 \mathrm{mo}$ & 89 & 93.0 (median) & $p 5^{\text {th }} 90.0 \%, p 95^{\text {th }} 96.0 \%$ \\
\hline Dueñas-Mesa ${ }^{9} / 2015^{7}$ & Colombia & 2640 & $13 \pm 1.9 \mathrm{mo}$ & 25 & 94.0 (median) & p5 $5^{\text {th }} 91.0 \%, p 95^{\text {th }} 96.0 \%$ \\
\hline Niermeyer/199329 & USA/active sleep & 3100 & $1 \mathrm{wk}$ & 14 & 83.0 (mean) & \pm 1 SD $5.6 \%$ \\
\hline Niermeyer/199329 & USA/quiet sleep & 3100 & $1 \mathrm{wk}$ & 14 & 80.6 (mean) & \pm 1 SD 5.3\% \\
\hline Niermeyer/199329 & USA & 3100 & $2 \mathrm{mo}$ & 13 & 86.6 (mean) & \pm 1 SD $4.7 \%$ \\
\hline Niermeyer/199329 & USA/quiet sleep & 3100 & $4 \mathrm{mo}$ & 14 & 86.6 (mean) & \pm 1 SD $4.4 \%$ \\
\hline Ucrós/201747 & Ecuador & 3200 & $1-4 \mathrm{mo}$ & 18 & 92.0 (median) & $p 5^{\text {th }} 66.0 \%, p 5^{\text {th }} 91.0 \%$ \\
\hline Niermeyer/199530 & China/Han & 3658 & $1-16 w k$ & 15 & 84.0 (mean) & \pm 1 SD $9 \%$ \\
\hline Niermeyer/1995 30 & China/Tibetan & 3658 & $1-16$ wk & 15 & 87.0 (mean) & \pm 1 SD $5 \%$ \\
\hline Hill/2016 11 & Bolivia & 3650 & $\begin{array}{c}7-10 \text { yrs } \\
13-16 \text { yrs }\end{array}$ & 26 & 89.0 (median) & IQR 3\% \\
\hline $\mathrm{Hill} / 2016^{12}$ & Bolivia & 3700 & $6-12 \mathrm{mo}$ & 7 & 87.5 (median) & IQR 7.7\% \\
\hline Hill/2016 12 & Bolivia & 3700 & $4-10 \mathrm{yrs}$ & 18 & 90.3 (median) & IQR $6.1 \%$ \\
\hline Hill/2016 12 & Bolivia & 3700 & 13-17 yrs & 7 & 91.2 (median) & IQR 3.1\% \\
\hline Ramírez-Cardich/2004 ${ }^{33}$ & Peru & 3750 & $2 w k$ & 14 & 86.2 & No data \\
\hline Ramírez-Cardich/2004 ${ }^{33}$ & Peru & 3750 & $1 \mathrm{mo}$ & 15 & 86.0 & No data \\
\hline Ramírez-Cardich/2004 ${ }^{33}$ & Peru & 3750 & $2 \mathrm{mo}$ & 20 & 87.5 & No data \\
\hline Ramírez-Cardich/200433 & Peru & 3750 & $3 \mathrm{mo}$ & 17 & 88.0 & No data \\
\hline
\end{tabular}




\begin{tabular}{|c|c|c|c|c|c|c|}
\hline Ramírez-Cardich/2004 & Peru & 3750 & $4 \mathrm{mo}$ & 12 & 89.2 & No data \\
\hline Gamponia/1998 & Bolivia & 4018 & $0-5 \mathrm{mo}$ & 12 & 84.6 (median) & Cl 95\% [81.3\%-87.9\%] \\
\hline
\end{tabular}

Table 6. $\mathrm{SpO}_{2}$ in feeding infants at different ages and high altitudes across the world

\begin{tabular}{|c|c|c|c|c|c|c|}
\hline Author/Year & Country & $\begin{array}{c}\text { Altitude } \\
\text { (masl) }\end{array}$ & Age range & $\mathbf{n}$ & $\begin{array}{c}\% \mathrm{SpO}_{2} \\
\text { mean }\end{array}$ & $\begin{array}{c}\text { Difference in } \mathrm{SpO}_{2} \% \text { with } \\
\text { the wake state }\end{array}$ \\
\hline Torres/199945 & Colombia & 2640 & $1-30$ days & 294 & 93.5 & Minus 1.5 \\
\hline Niermeyer/1993 29 & USA & 3100 & $1 \mathrm{wk}$ & 14 & 85.8 & Minus 3.0 \\
\hline Niermeyer/199329 & USA & 3100 & $2 \mathrm{mo}$ & 13 & 89.5 & Minus 0.4 \\
\hline Niermeyer/199329 & USA & 3100 & $4 \mathrm{mo}$ & 14 & 90.9 & Minus 0.2 \\
\hline Niermeyer/1995 30 & China/Han & 3658 & $1 \mathrm{wk}$ & 15 & 85 & Minus 2 \\
\hline Niermeyer/199530 & China/Han & 3658 & $1 \mathrm{mo}$ & 15 & 81 & Minus 4 \\
\hline Niermeyer/1995 30 & China/Han & 3658 & $2 \mathrm{mo}$ & 11 & 80 & Minus 2 \\
\hline Niermeyer/199530 & China/Han & 3658 & $4 \mathrm{mo}$ & 9 & 79 & Minus 6 \\
\hline Niermeyer/1995 30 & China/Tibetan & 3658 & $1 \mathrm{wk}$ & 15 & 87 & Minus 3 \\
\hline Niermeyer/199530 & China/Tibetan & 3658 & $1 \mathrm{mo}$ & 15 & 86 & Minus 3 \\
\hline Niermeyer/199530 & China/Tibetan & 3658 & $2 \mathrm{mo}$ & 13 & 86.5 & Minus 2 \\
\hline Niermeyer/199530 & China/Tibetan & 3658 & $4 \mathrm{mo}$ & 13 & 86 & Minus 0.5 \\
\hline Ramírez-Cardich /200433 & Peru & 3750 & 2 wk & 13 & 88 & Minus 3.0 \\
\hline Ramírez-Cardich /2004 33 & Peru & 3750 & $1 \mathrm{mo}$ & 16 & 89.5 & Minus 2.5 \\
\hline Ramírez-Cardich /2004 33 & Peru & 3750 & $2 \mathrm{mo}$ & 21 & 90.5 & Minus 1.5 \\
\hline Ramírez Cardich / $2004^{33}$ & Peru & 3750 & $3 \mathrm{mo}$ & 13 & 91 & Minus 1.0 \\
\hline Ramírez-Cardich /200433 & Peru & 3750 & $4 \mathrm{mo}$ & 20 & 91.5 & Minus 0.5 \\
\hline Gamponia/19988 & Bolivia & 4018 & $0-5 \mathrm{mo}$ & 4 & 83.5 & Minus 3.5 \\
\hline
\end{tabular}




\begin{tabular}{|c|c|c|c|c|c|}
\hline Age (years) & Altitude (masl) & $\mathrm{SpO}_{2}$ median Quartile 1 $(\mathrm{n})$ & $\mathrm{SpO}_{2}$ median Quartiles 2-4 (n) & $\mathrm{SpO}_{2}$ difference & $\mathrm{p}$-value \\
\hline $1-5$ & 2500 & $94 \%(21)$ & $96 \%(66)$ & $2 \%$ & $<0.001$ \\
\hline $6-17$ & 2500 & $95 \%(58)$ & $97 \%(176)$ & $2 \%$ & $<0.001$ \\
\hline $1-5$ & 3600 & $88 \%(8)$ & $93 \%(30)$ & $5 \%$ & $<0.001$ \\
\hline $6-17$ & 3600 & $91 \%(29)$ & $93 \%(88)$ & $2 \%$ & $<0.001$ \\
\hline $1-5$ & 5100 & $75 \%(19)$ & $81 \%(168)$ & $6 \%$ & $<0.001$ \\
\hline $6-17$ & 5100 & $77 \%(41)$ & $82 \%(131)$ & $5 \%$ & $<0.001$ \\
\hline
\end{tabular}

Table 7. Differences in SpO2 between Quartiles 1 and Quartiles 2 to 4 at several altitudes and groups of age

Table built with data from Rojas-Camayo J, (2018). Ref 35.

Figure 1. Process of study selection

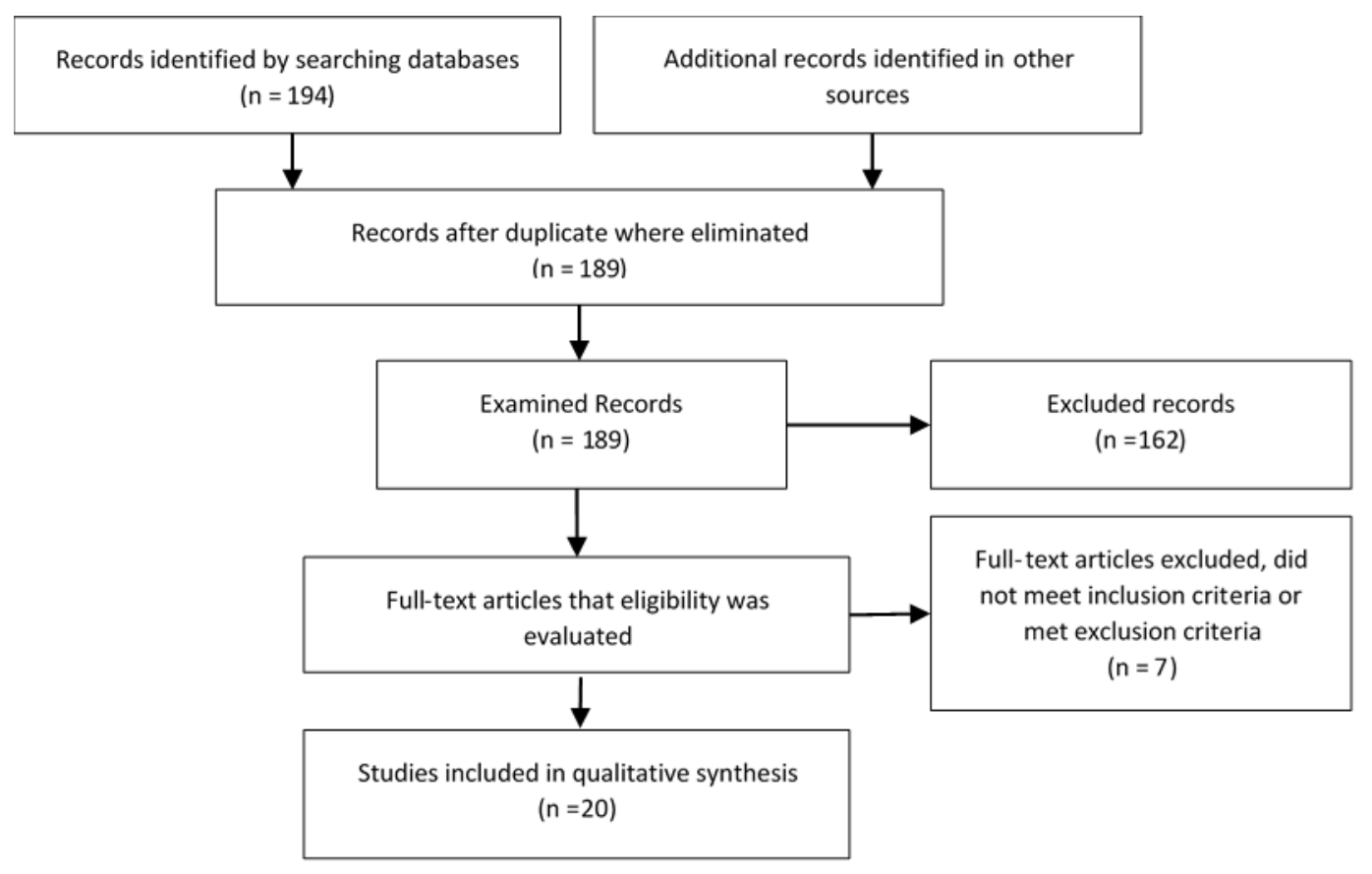


Figure 2. $\mathrm{SpO}_{2} 5^{\text {th }}$ percentile at different altitudes in two age groups in Peru

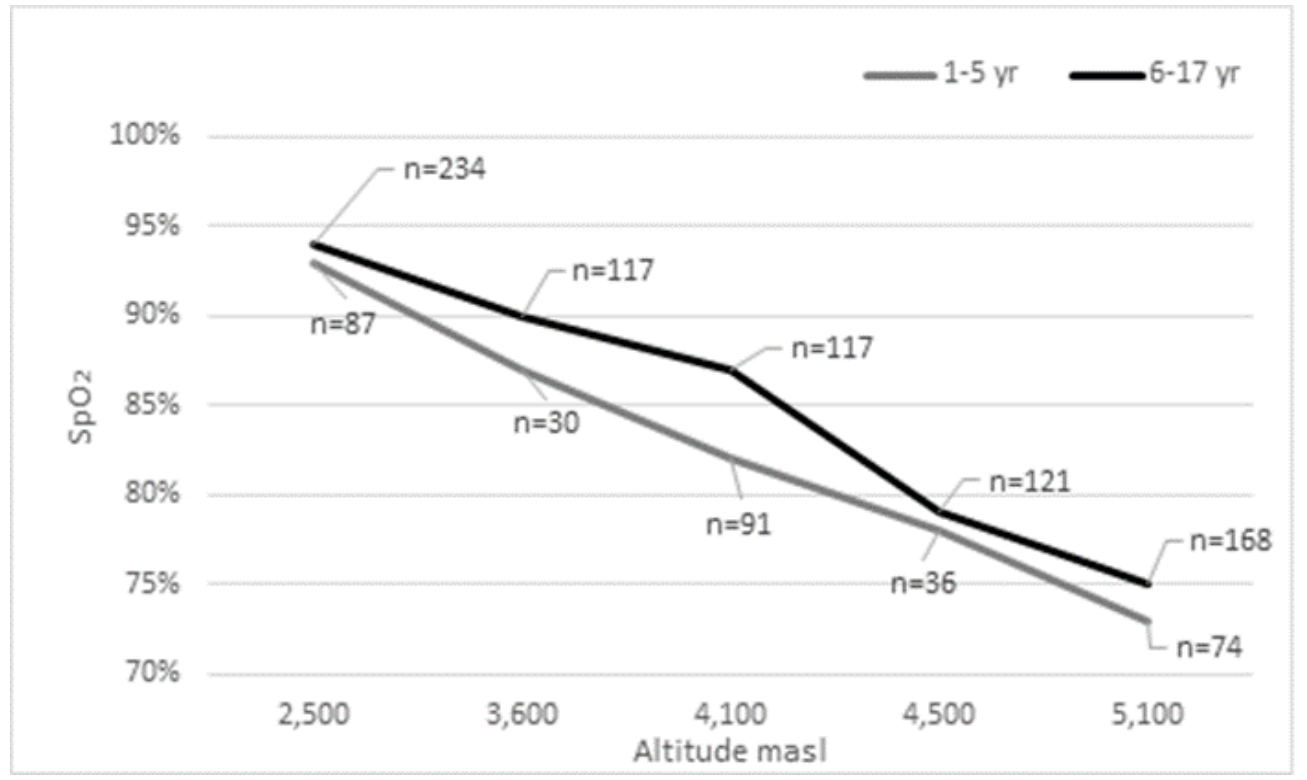

Graphic built with data from Rojas-Camayo J, (Ref 35$) .5^{\text {th }}$ centile data provided to offer potential thresholds below which children require further clinical evaluation.

Figure 3. Gap between $\mathrm{SpO}_{2}$ medians in wake and sleep states in children from 6 months to 17 years of age at 3,700 masl in Bolivia

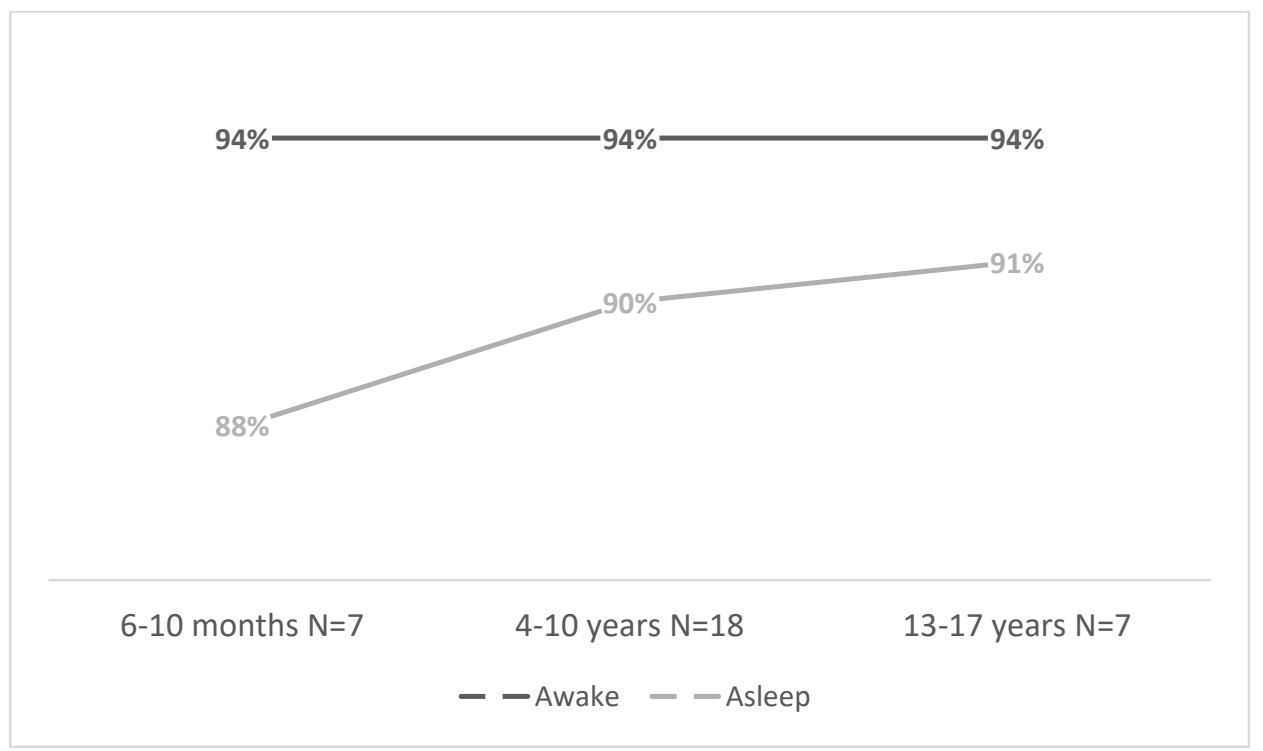

At low altitude $\mathrm{SpO}_{2}$ developmental differences were evident between infants and children in relation with $3 \%$ dips, and were statistical significant $(p=0.019)$. These differences were more striking at high altitude ( $p<0.001)$. Graphic built with data from Hill CM et al. (Ref: 12). 
Figure 4. $\mathrm{SpO}_{2}$ at 2,640 masl in awake and asleep infants from 3 to 15 months of age in Colombia

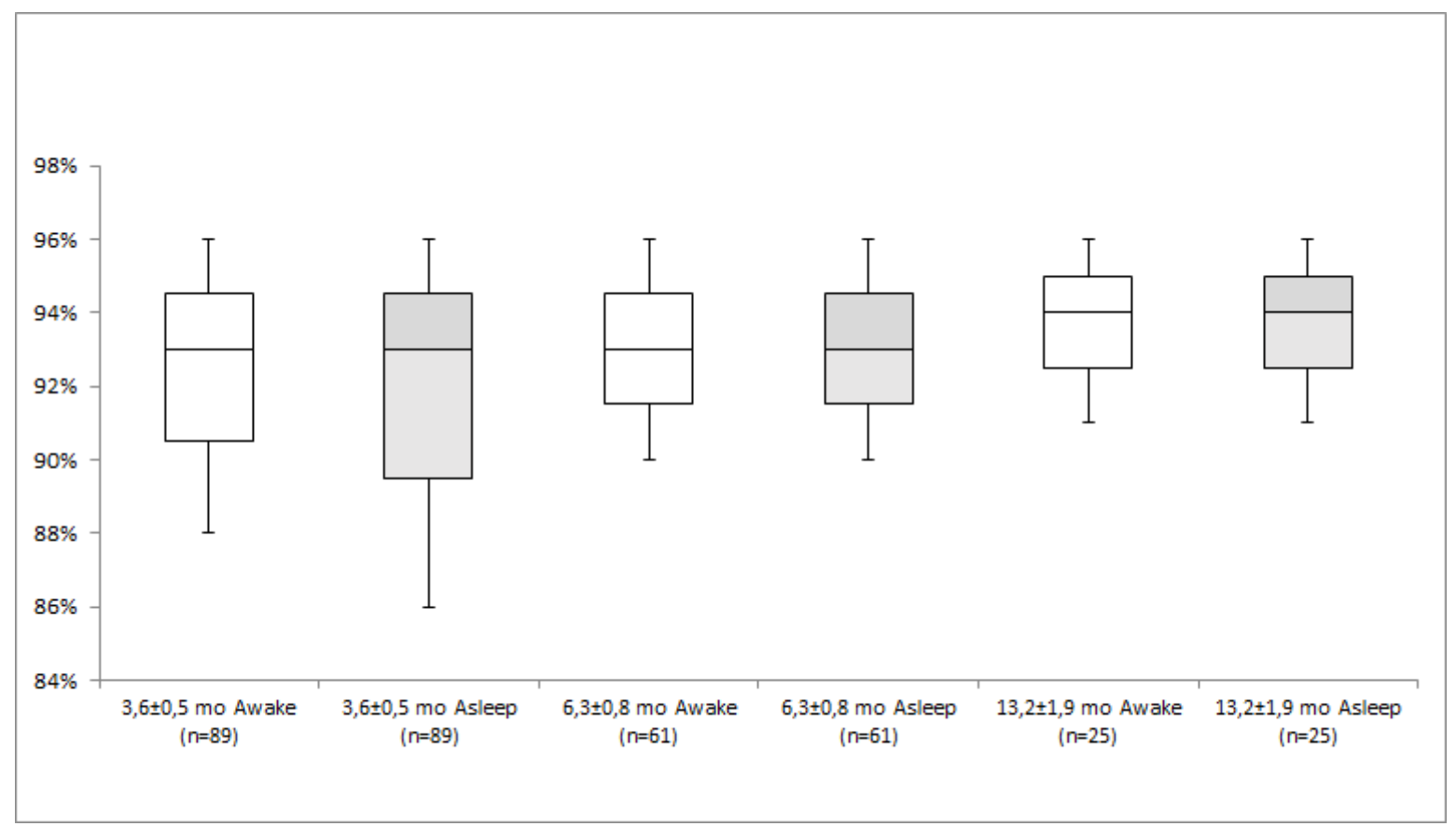

In 3,6 $\pm 0,5$ months subjects (awake and asleep) $\mathrm{SpO}_{2}$ nadir, time with $\mathrm{SpO}_{2}<90 \%$ and oxygen desaturation index were significantly higher in comparison in the two other groups of age $(p<00.1)$. Graphic built with data from: Dueñas-Meza et al. (Ref 7). 
Figure 5. Consistent $\mathrm{SpO}_{2}$ left skew at different altitudes and age groups

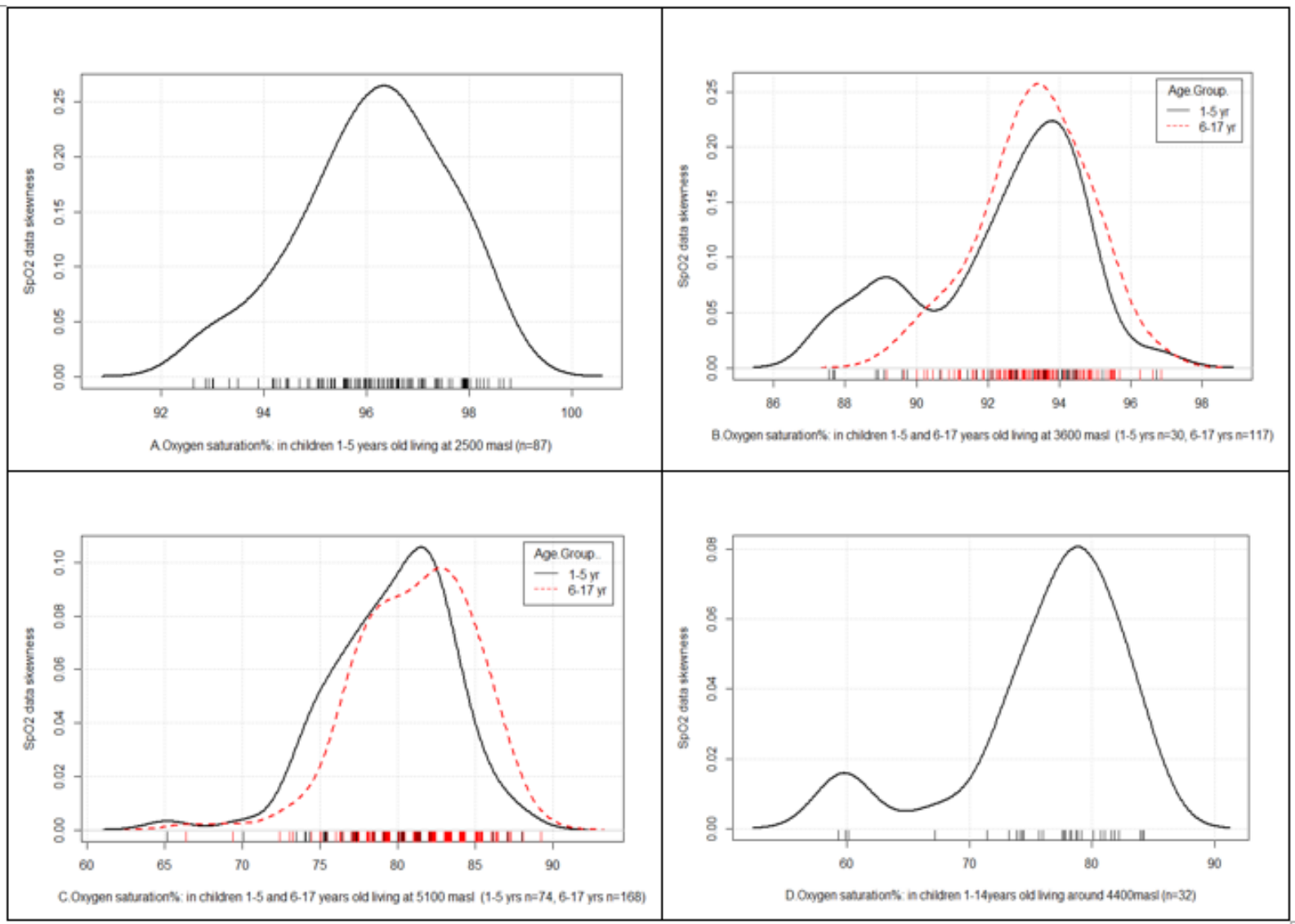

Graphics A,B and C built with data from Rojas-Camayo J et al. (Ref 35). Graphic D built with data from Sime et al. (Ref 40). The original paper from Sime shows results in means and SD. As the article delivers data of each of the children, we looked for the statistical distribution for SpO2 and built the graphic.

Figure $6 . \mathrm{SpO}_{2}$ difference between $5^{\text {th }}$ and $95^{\text {th }}$ percentile in two age groups at different altitudes

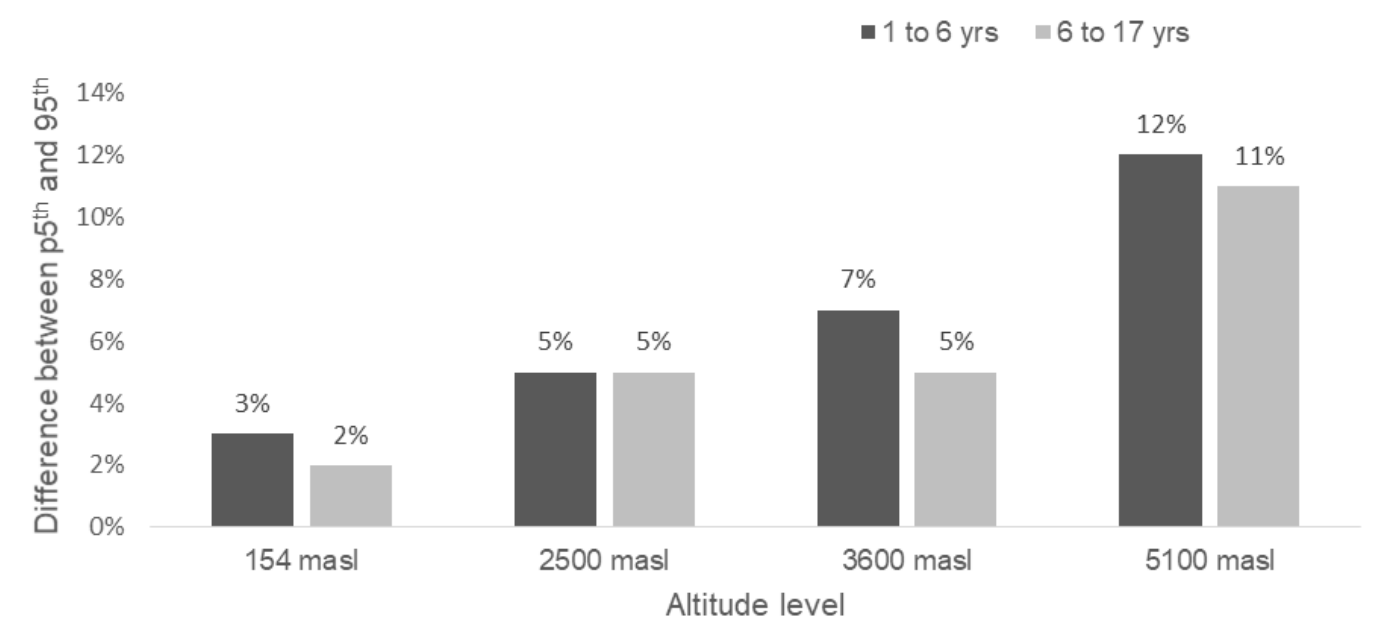

Graphic built with data from Rojas-Camayo et al. (Ref 35). 
Figure 7. Comparison between the oxygen-hemoglobin dissociation curve and $\mathrm{SpO}_{2}$ curve as oxygen partial pressure increases.

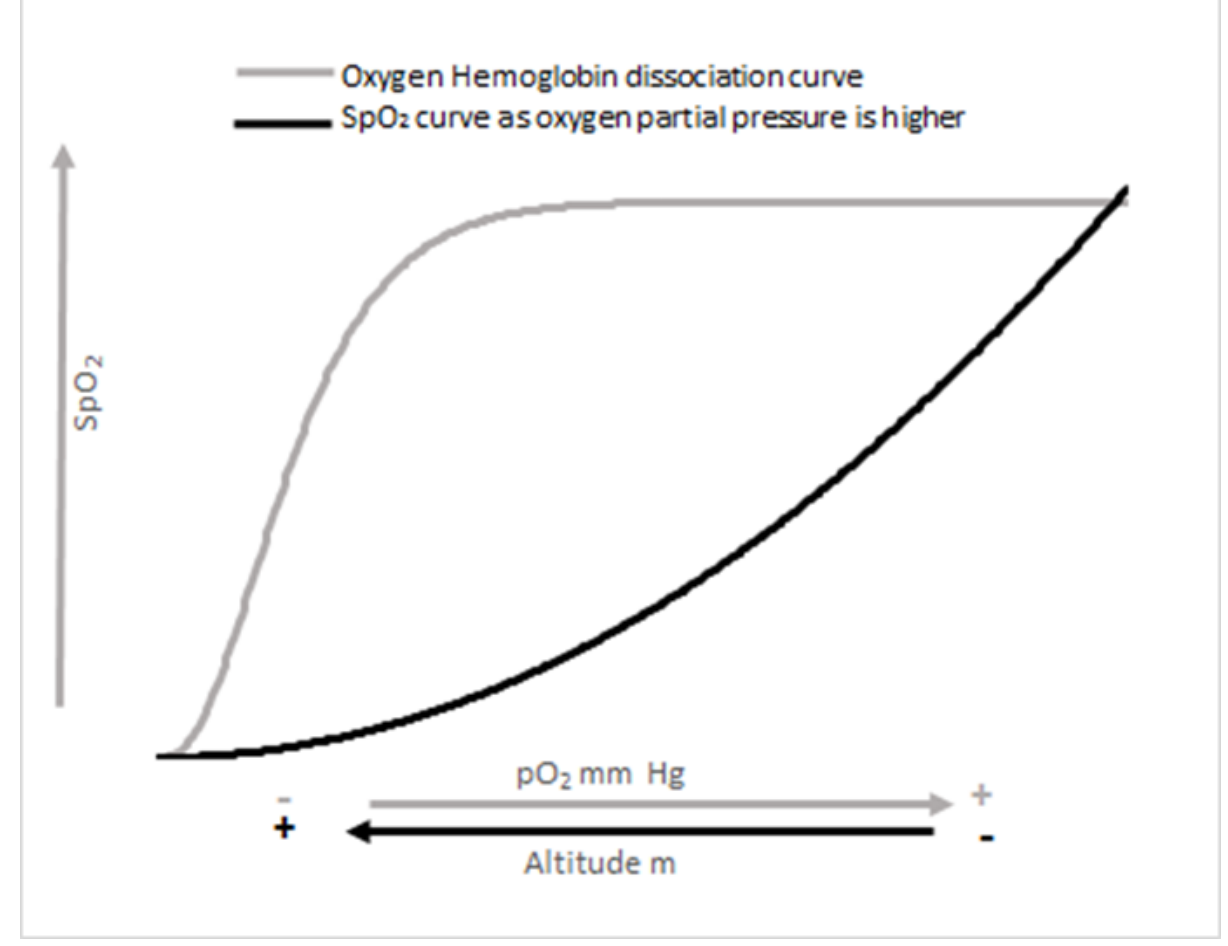

Graphic built with data from Chernick V, West JB (Ref 6) and Penaloza D, Arias-Stella J (Ref 32). 